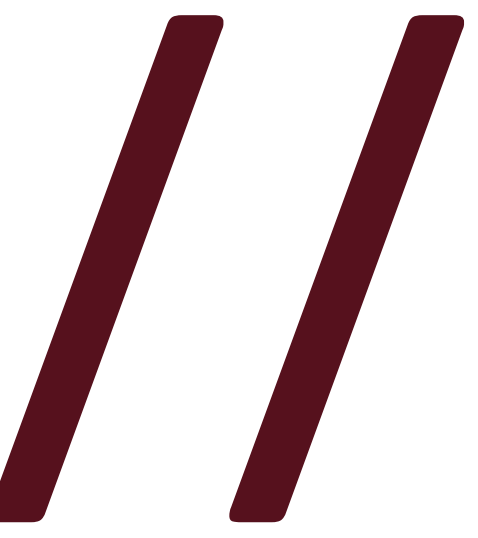

\title{
A singularidade de
} "Vereda tropical" sob um olhar bakhtiniano The singularity of "Vereda tropical" under a
bakthinian approach

Alexandre Silva Guerreiro ${ }^{1}$

\footnotetext{
${ }^{1}$ Doutor em Comunicação pelo Programa de Pós-Graduação em Comunicação (PPGCOM) da Universidade Federal Fluminense (UFF). Mestre em Comunicação pelo PPGCOM-UFF. Bacharel e licenciado em História pela Universidade do Estado do Rio de Janeiro (UERJ). Bacharel em Cinema pela UFF. Atualmente é Professor Docente I na Secretaria de Educação do Estado do Rio de Janeiro e desenvolve pesquisa de pósdoutorado sobre Educação, Cinema e Violência no PPGE/UFRJ. E-mail: alexandreguerreiro@hotmail.com
} 
Resumo: este artigo busca compreender o alcance e interdependência dos conceitos de carnavalização e de grotesco, desenvolvidos por Mikhail Bakhtin, tendo como objeto de análise "Vereda tropical", de Joaquim Pedro de Andrade, uma das obras mais ousadas do cinema brasileiro. Ao criar o conceito de cosmovisão carnavalesca, Bakhtin possibilitou um novo olhar sobre a obra de arte. Somada ao grotesco realista, a carnavalização possibilita novas chaves para o visionamento de um filme. No caso de "Vereda tropical", a atualidade e vanguardismo atestam sua importância quando confrontados à cena contemporânea do cinema brasileiro, a partir do imbricamento dos conceitos backhtinianos aqui abordados.

Palavras-chave: carnavalização; grotesco; Bakhtin; Vereda tropical.

Abstract: this paper aims to understand the scope and permanence of the concepts of carnivalization and grotesque, developed by Mikhail Bakhtin, and analyzing "Vereda tropical", directed by Joaquim Pedro de Andrade, one of the most audacious works of Brazilian cinema. In creating the concept of carnivalization, Bakhtin made possible a new look at a work of art. Added to the realistic grotesque, carnivalization provides new keys for viewing a movie. In the case of "Vereda tropical", produced in 1977, the current and avant-gardism attest to its importance when confronted with the contemporary scene of Brazilian cinema, considering the overlapping of the backhtinian concepts discussed here.

Keywords: carnavalization; grotesque; Bakhtin; Vereda tropical. 
O cinema brasileiro segue certa tradição dentro do universo da carnavalização e do grotesco. Como ferramentas de análise, esses conceitos nos ajudam a pensar o cinema dentro de uma nova chave. Nesse sentido, a abordagem de filmes como A marvada carne (1985), de André Klotzel, Carlota Joaquina, princesa do Brasil (1995), de Carla Camurati ou mesmo Amélia (2000), de Ana Carolina, entre outros, ganha uma dimensão impossível de se conseguir sem nos aproximarmos do pensamento de Mikhail Bakhtin. O caso mais radical em nossa cinematografia, no entanto, é anterior aos exemplos supracitados e permanece como uma espécie de vanguarda audiovisual quando comparado à cena contemporânea do cinema. Trata-se de "Vereda tropical", filme dirigido por Joaquim Pedro de Andrade em 1977.

O presente artigo tem por objetivo analisar esse filme à luz dos conceitos da carnavalização e do grotesco desenvolvidos por Bakhtin. De que maneira esses conceitos nos ajudam a entender a atualidade do filme em questão e sua singularidade? Inicialmente, traçaremos uma breve análise dos conceitos aqui trabalhados separadamente, salientando a indivisibilidade dos mesmos para, em seguida, apontarmos a relevância de sua junção numa mesma equação. Por fim, analisaremos o filme "Vereda tropical", ressaltando os elementos que o inscrevem nesse universo conceitual bakhtiniano.

\section{Da indivisibilidade: os conceitos de carnavalização e de grotesco em Bakhtin}

O carnaval, segundo Bakhtin,

É uma forma sincrética de espetáculo de caráter ritual, muito complexa, variada, que, sob base carnavalesca geral, apresenta diversos matizes e variações dependendo da diferença de épocas, povos e festejos particulares. O carnaval criou toda uma linguagem de formas concreto-sensoriais simbólicas, entre grandes e complexas ações de massas e gestos carnavalescos. Essa linguagem exprime de maneira diversificada e, pode-se dizer, bem articulada (como toda linguagem) uma cosmovisão carnavalesca una (porém complexa), que lhe penetra todas as formas. (BAKHTIN, 1982, p. 105)

A concepção bakhtiniana do carnaval passa pela definição de três grandes categorias. Bakhtin estabelece que a ideia maior do carnaval ultrapassa a materialidade das festas populares, que constituem a primeira categoria, a saber, as formas dos ritos e espetáculos, desembocando em outras duas categorias, a das obras cômicas verbais e a das diversas formas e gêneros do vocabulário familiar e grosseiro. É essa visão amplificada do fenômeno do carnaval que permitiu a formulação do conceito de carnavalização e outros conceitos correlatos. 
As formas dos ritos e espetáculos traduzem-se como o carnaval concreto, das festividades carnavalescas que rompiam com as tradições religiosas e oficiais, e instauravam outra tradição, a do cômico-popular, do riso, do extraoficial. Segundo Bakhtin, os que participavam dessas festividades "pareciam ter construído, ao lado do mundo oficial, um segundo mundo e uma segunda vida [...]. Isso criava uma espécie de dualidade do mundo" (BAKHTIN, 1993, p. 5, grifos do autor).

As obras cômicas verbais, segundo Bakhtin, poderiam vir tanto do folclore e de uma tradição oral quanto da literatura, através de uma absorção das manifestações de ordem carnavalesca. Assim, tanto o linguajar quanto o riso festivo próprio do carnaval eram usados, formulando essa literatura cômica própria da Idade Média, e que teve no Renascimento seu apogeu.

As diversas formas e gêneros do vocabulário familiar e grosseiro foram apontadas por Bakhtin como essenciais para se entender o carnaval como um todo. Esse vocabulário específico está presente tanto nas festividades populares como na literatura cômica que se formulou no período. Era uma forma nova de se comunicar, imbuída do espírito do carnaval, que se desdobrava no uso frequente de grosserias. O uso desse linguajar específico se dá graças à convivência familiar entre os homens que o carnaval suscita.

É importante distinguir de que carnaval nos fala Bakhtin ao propor essa transposição. O carnaval é uma festa popular que atravessou a História, sendo dentre todas as manifestações da cultura popular, a mais consistente e tradicional para servir de base à transposição bakhtiniana. Assim, ele nos fala do carnaval como símbolo das festas populares.

O carnaval revela-nos o elemento mais antigo da festa popular, e pode-se afirmar sem risco de erro que é o fragmento mais bem conservado desse mundo tão imenso quanto rico. Isso autoriza-nos a utilizar o adjetivo "carnavalesco" numa acepção ampliada, designando não apenas as formas do carnaval no sentido estrito e preciso do termo, mas ainda toda a vida rica e variada da festa popular no decurso dos séculos. (BAKHTIN, 1993, p. 189-190)

Durante séculos, os homens conviveram com e no carnaval, deixando-se contaminar por uma visão de mundo própria ao universo de inversões e rupturas dos festivos carnavalescos. Essa contaminação nos permite supor que determinadas obras não se enquadram nos cânones clássicos da literatura e da arte em geral. O conceito de cosmovisão carnavalesca vem batizar uma prática de leitura do mundo 
contaminada pela essência do carnaval. A carnavalização se dá através da influência de diferentes modalidades de folclore carnavalesco na arte (BAKHTIN, 1982, p. 92).

Ao aproximar o homem do mundo, e o homem do homem, o conceito de carnavalização promove uma transformação na abordagem de certos temas e propostas estéticas. Isso porque a carnavalização descortina uma pluralidade de estilos e vozes na corrente do gênero cômico. Segundo Diana Barros, os textos carnavalizados "diferenciam-se, portanto, dos discursos autoritários, graças à polêmica narrativa, à polifonia, $[\ldots]$ recursos pelos quais se obtém a visão do direito e do avesso do mundo" (BARROS, 2003, p. 8).

Dentre as muitas características que podem ser ressaltadas quando enfocamos a carnavalização, a ideia de inversão, sem dúvida, assume destaque pois está no cerne da própria abordagem do carnaval feita por Bakhtin. A inversão que o carnaval promove na vida cotidiana foi responsável pela sedimentação de uma visão de mundo carnavalizada.

Um dos pontos fundamentais é a ideia de que o carnaval é responsável pela aproximação entre os homens, que na vida cotidiana permanecem afastados social e hierarquicamente. Essa aproximação específica promovida pelo carnaval transforma-se, então, no livre contato familiar entre os homens. Instaura-se um novo modo de relações interpessoais, a partir da formulação do contato livre e familiar.

A esse conceito, Bakhtin atrela outra característica importante do mundo carnavalizado, a saber, a excentricidade. Para ele,

A excentricidade é uma categoria específica da cosmovisão carnavalesca, organicamente relacionada com a categoria do contato familiar; ela permite que se revelem e se expressem em forma concreto-sensorial - os aspectos ocultos da natureza humana. (BAKHTIN, 1982, p. 106, grifo do autor)

Paralelamente à carnavalização, o conceito de grotesco é fundamental dentro do universo bakhtiniano. No entanto, alguns autores que pensaram o grotesco, ao discorrerem sobre o assunto, caminharam em sentidos diferentes do percorrido por Bakhtin, razão pela qual torna-se necessário decantar o conceito para registrar qual grotesco serve ao princípio da carnavalização.

A origem do termo grotesco pode ser apreendida através de Bakhtin, que nos fala de seu surgimento, no final do século XV, quando

Escavações feitas em Roma nos subterrâneos das Termas de Tito trazem à luz um tipo de pintura ornamental até então desconhecida. Foi chamada de grottesca, derivado do 
substantivo italiano grotta (gruta). Um pouco mais tarde, decorações semelhantes foram descobertas em outros lugares da Itália. (BAKHTIN, 1993, p. 28, grifos do autor)

Victor Hugo, Wolfgang Kayser, Mikhail Bakhtin e, no Brasil, mais expressivamente, Muniz Sodré, são alguns dos autores que se debruçaram sobre o tema. O grotesco aparece muito antes, desde a Antiguidade, sem ter sido devidamente conceituado. Já nesses autores, observamos uma preocupação em articular uma conceituação acerca do grotesco. Porém, os autores citados não falam de um mesmo grotesco. O conceito utilizado por Bakhtin, a saber, o grotesco realista, se distancia do grotesco romântico, que encontra em Vitor Hugo seu principal representante.

Victor Hugo teorizou sobre o grotesco ainda no século XIX, mais precisamente em 1827, ao escrever o prefácio de uma peça teatral, a saber, Cromwell. Ao discorrer sobre a modernidade do drama, Victor Hugo deixou registrado um verdadeiro tratado acerca do grotesco, definido em oposição à ideia de sublime. Ainda que esse prefácio contenha uma duvidosa divisão da história da humanidade, pouco aceita, que reduz a experiência humana a três tempos vinculados à poesia, que também se manifestaria em três idades², foi mesmo na sua explanação sobre o grotesco que figurou o maior interesse sobre essa obra.

O grotesco romântico é característico do drama moderno, e busca incessantemente minar a estética clássica. A tradição do classicismo é minada, inclusive, pelo cristianismo profundamente presente em Hugo. O autor preocupa-se em valorizar categorias dicotômicas, cristianismo e classicismo, corpo e espírito. O mesmo dualismo estará presente na conceituação do sublime e do grotesco, colocados em posição de antagonismo por Hugo.

A musa moderna verá as coisas com um olhar mais elevado e mais amplo. Sentirá que tudo na criação não é humanamente belo, que o feio existe ao lado do belo, o disforme perto do gracioso, o grotesco no reverso do sublime, o mal com o bem, a sombra com a luz. (HUGO, 1988, p. 25)

Para Hugo, a marca da modernidade é o drama, e a presença do grotesco ao lado do sublime, uma prova da evolução da arte. Hugo afirma que a Antiguidade não teria feito A Bela e a Fera, por exemplo. É bom lembrar que, da mesma forma, somente o espírito moderno permitiu que o próprio Hugo desenhasse na literatura

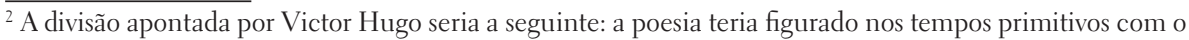
lirismo, nos tempos antigos com a epopeia e nos tempos modernos com o drama.
} 
o corcunda Quasímodo, encerrado na torre da Catedral de Notre-Dame, servindo como ícone da sublimação do grotesco promovida pelo seu criador.

Ainda que Hugo se coloque constante e ferozmente contra a estética clássica, é interessante registrar que, em mais de um momento, ele entende que a união do sublime e do grotesco existe a partir de uma evolução da arte, e considera o passado como elemento fundamental para que a poesia tenha chegado no nível de sua época, a da modernidade.

Sobre Hugo, Muniz Sodré e Raquel Paiva afirmam que ele partiu "de algo que já estava no ar, no espírito de seu tempo” (SODRÉ; PAIVA, 2002, p. 46). Porém, é preciso levar em conta que, ainda que o espírito do romantismo estivesse imbuído das ideias que Hugo considerou, ou mesmo que o grotesco tenha, em estado embrionário, aparecido já na Antiguidade, foi o prefácio em questão o primeiro momento em que a categoria do grotesco encontrou uma tentativa sistemática de teorização.

Para Bakhtin, “o grotesco romântico é um grotesco de câmara, uma espécie de carnaval que o indivíduo representa na solidão, com a consciência aguda de seu isolamento" (BAKHTIN, 1993, p. 33). Na verdade, Bakhtin utiliza o grotesco romântico em oposição à categoria do realismo grotesco ${ }^{3}$.

Entre Victor Hugo e Wolfgang Kayser, mais de um século se passou. Outros autores, nesse intervalo, tangenciaram o tema ${ }^{4}$. Não nos deteremos sobre os outros nomes pois nossa intenção é privilegiar os autores que se preocuparam em desenvolver o conceito de grotesco para, com isso, refletirmos sobre o grotesco que serve à carnavalização. Assim, é na década de 1950 do século XX que surge o trabalho de Wolfang Kayser que nos interessa destacar.

Em 1957, Kayser tenta preencher essa lacuna de um século na qual a conceituação do grotesco não havia avançado. Seu livro O grotesco surge de sua inquietação diante da pintura, mais especificamente quando da sua primeira visita ao Museu do Prado, 15 anos antes do lançamento do livro. De maneira esquemática, Kayser busca responder diversas questões, desde a conceituação do grotesco até a ampliação do conceito e sua definição dentro do romantismo do século XIX.

Kayser promove um avanço em relação às especulações de Hugo. Sua pesquisa tenta detectar, no seio da tradição cultural ocidental, uma categoria estética não reconhecida. Assumindo uma perspectiva histórica, Kayser salienta que o fenômeno do grotesco é mais antigo que seu nome. No entanto, Bakhtin faz uma

\footnotetext{
${ }_{3}^{3}$ Cabe salientar que Bakhtin faz, também, uma distinção entre o realismo grotesco, próprio da Idade Média e do Renascimento, e o grotesco realista, que teria surgido já no século XX. Este assumiria as mesmas características daquele. A distinção apontada por Bakhtin é, sobretudo, temporal.

${ }^{4}$ Bakhtin aponta, entre outros, Nietzsche, Baudelaire, Gautier e Schlegel, esse último antes de Hugo.
} 
severa crítica ao arsenal teórico de Kayser por julgar insuficientes as observações deste sobre a essência do grotesco. "Kayser propôs-se a escrever uma teoria geral do grotesco, a revelar a própria essência do fenômeno [...] razão pela qual ele o compreende e aprecia de uma forma um pouco desvirtuada” (BAKHTIN, 1993, p. 41).

Bakhtin promove uma ruptura em relação à conceituação do grotesco que o precede. Para ele, as imagens de Rabelais funcionam como herança da cultura cômica popular e servem como distinção das culturas dos séculos precedentes. Essa concepção que segue o princípio material e corporal é batizada por Bakhtin de realismo grotesco. No realismo grotesco (isto é, no sistema de imagens da cultura cômica popular), "o princípio material e corporal aparece sob a forma universal, festiva e utópica. O cósmico, o social e o corporal estão ligados indissoluvelmente numa totalidade viva e indivisível" (BAKHTIN, 1993, p. 17).

O mais importante na concepção do realismo grotesco bakhtiniano é a ideia de rebaixamento, que consiste em trazer para o plano material e corporal, para a terra, aquilo que é considerado como elevado, espiritual. Esse valor topográfico perpassa as abordagens que Bakhtin tece sobre a obra de Rabelais. O alto e o baixo são, assim, relativos, respectivamente, ao céu e à terra e, também, à cabeça e aos órgãos genitais. O conceito de grotesco utilizado por Bakhtin, ou seja, o grotesco realista, se distancia do grotesco romântico.

Assim, Bakhtin passa a limpo a formulação do grotesco enquanto categoria e deixa em evidência o grotesco realista que ele aponta como característico de uma tradição da cultura cômica popular. Sobre Bakhtin e suas considerações acerca do grotesco, Sodré e Paiva afirmam:

A partir da modelagem carnavalesca, entende-se por que o grotesco subverte as hierarquias, as convenções e as verdades socialmente estabelecidas. Subverte igualmente as figurações clássicas do corpo, passando a valorizar as vinculações corporais com o universo material, assim como seus orifícios, protuberâncias e partes baixas. (SODRÉ; PAIVA, 2002, p. 59)

Além disso, a comida e o sexo representam uma particularidade da imagem grotesca do corpo, que deglute e vomita. A prática do coito, a absorção de alimentos e a satisfação de necessidades naturais pertencem ainda ao universo de degradações próprias de uma visão grotesca do mundo. Sendo assim, o conceito de carnavalização como instrumento de análise ganha um poderoso aliado com a noção bakhtiniana de grotesco.

Segundo Bakhtin, esses conceitos não estão isolados. Assim como paródia, sátira e tantos outros conceitos por ele trabalhados, são correlatos. O pensamento 
bakhtiniano aponta o grotesco realista como complementar à cosmovisão carnavalesca. Trata-se de amplificar as condições em que se dá a carnavalização, que tem o riso como fundamento, atentando para uma tradição cômica popular que atravessou a Idade Média e o Renascimento.

Assim, a soma da inversão carnavalesca e do rebaixamento grotesco leva a um conceito uno e indivisível que chamaremos de grotesco-carnavalizado. Bakhtin afirma dar à categoria do rebaixamento o nome convencional de realismo grotesco (BAKHTIN, 1993, p. 17), o que cria uma dificuldade inicial que é a filiação desse grotesco à escola realista, sobretudo quando pensamos o cinema. O próprio Bakhtin se questiona sobre a pertinência do termo, explicando que assim o define em oposição à escola modernista/romântica.

Mas até que ponto se justifica nossa denominação de "realismo grotesco"? [...] As características que diferenciam de maneira tão marcante o grotesco medieval e renascentista do grotesco romântico e modernista - principalmente a compreensão espontaneamente materialista e dialética da existência podem ser definidas da maneira mais adequada como realistas. (BAKHTIN, 1993, p. 45, grifo do autor)

Alguns estudos se privam de definir qual grotesco serve ao conceito de carnavalização; outros, mesmo definindo, aplicam indiscriminadamente o grotesco na leitura de obras de arte. Acreditamos que a ligação entre grotesco e carnaval é fundamental para evitar confusões, ao que nos serve particularmente o termo grotesco- carnavalizado. Vale salientar que, ao mesmo tempo em que opta pelo termo grotesco realista, Bakhtin utiliza, eventualmente, a expressão grotesco carnavalesco, antecipando a necessidade da junção de ambos os conceitos numa mesma equação.

\section{O grotesco-carnavalizado em "Vereda tropical"}

O grotesco-carnavalizado como ferramenta de análise nos permite lançar uma visão diferenciada sobre a produção cinematográfica brasileira, que oferece um banquete de filmes passíveis de serem visionados por essa chave. Desde inúmeros exemplos das chanchadas, passando pelo cinema tropicalista ou marginal, ou mesmo pelas comédias de Mazzaropi, o cinema brasileiro parece ter uma tradição de visão de mundo grotesco-carnavalizada em suas narrativas audiovisuais. Nesse cenário, o filme "Vereda tropical" pode ser entendido como um exemplar muito particular do grotesco-carnavalizado no cinema brasileiro. 
"Vereda tropical" é um dos quatro episódios do longa-metragem Contos eróticos. O roteiro é baseado em contos, selecionados e premiados, da Revista Status 5 . O conto que nos interessa aqui é o que originou o último episódio do filme, dirigido por Joaquim Pedro de Andrade. Os demais episódios são "Arroz e feijão", dirigido por Roberto Santos, "As três virgens", dirigido por Roberto Palmari e "O arremate", dirigido por Eduardo Escorel. Mas o interesse geral em Contos eróticos está mesmo no episódio de Joaquim Pedro, um verdadeiro marco no uso do grotesco-carnavalizado.

"Vereda tropical" foi inspirado no conto escrito por Pedro M. Soares ${ }^{6}$. O filme narra a irreverente história de um professor universitário que tem compulsão sexual por melancias. As sequências em que o protagonista se relaciona sexualmente com as melancias são absolutamente singulares, tomando como referência a cinematografia nacional ou internacional.

A primeira inversão carnavalesca é a da própria figura do professor. A caracterização do personagem principal, vivida por Cláudio Cavalcanti, é marcada por trejeitos e hábitos pouco convencionais. Ao conversar com uma amiga, interpretada por Cristina Aché, sobre sua tese, a inversão e o abandono da austeridade própria do seu lugar ficam claros através do diálogo que segue, quando relata sua sensação depois de transar com e matar uma melancia. Sua amiga e confidente contribui para a inversão do espaço acadêmico e para o rebaixamento do lugar ocupado pelo professor catedrático.

Professor: Para mim, escrever a tese é um negócio repousante, feito música depois do crime. O parentesco colateral entre os nordestinos imigrados na construção civil do Rio de Janeiro. Amiga: Assim essa sua tese vai ficar chatíssima. Você tem que dar um jeito de encaixar a melancia aí na construção civil. Põe um apêndice no final comparando o uso da melancia pelos operários e pelos solitários de classe média. Ficava uma tese política e de sacanagem! (CONTOS ERÓTICOS, 1977)

O filme começa com a chegada do professor em casa carregando uma melancia. Durante essa primeira sequência, percebemos a intensidade do rebaixamento que o filme promove e de que maneira o princípio do material e do corporal compõe a gramatura do filme. O professor, sempre abraçado com a melancia, tira a camisa, a calça e molha a melancia na pia. De cueca, ele entra no chuveiro,

\footnotetext{
${ }^{5}$ Revista masculina editada na década de 1970 pela Editora Três.

${ }^{6}$ Além de ter sido publicado na Revista Status, em 1976, o conto foi publicado novamente no segundo número da Revista Ácaro, em 2003.
} 
pega um sabonete e ensaboa com carinho a melancia. A música de "Vereda tropical" aumenta o tom de irreverência. O professor carrega a melancia até uma mesa, passa talco e, finalmente, abre um orifício que utilizará para penetrá-la.

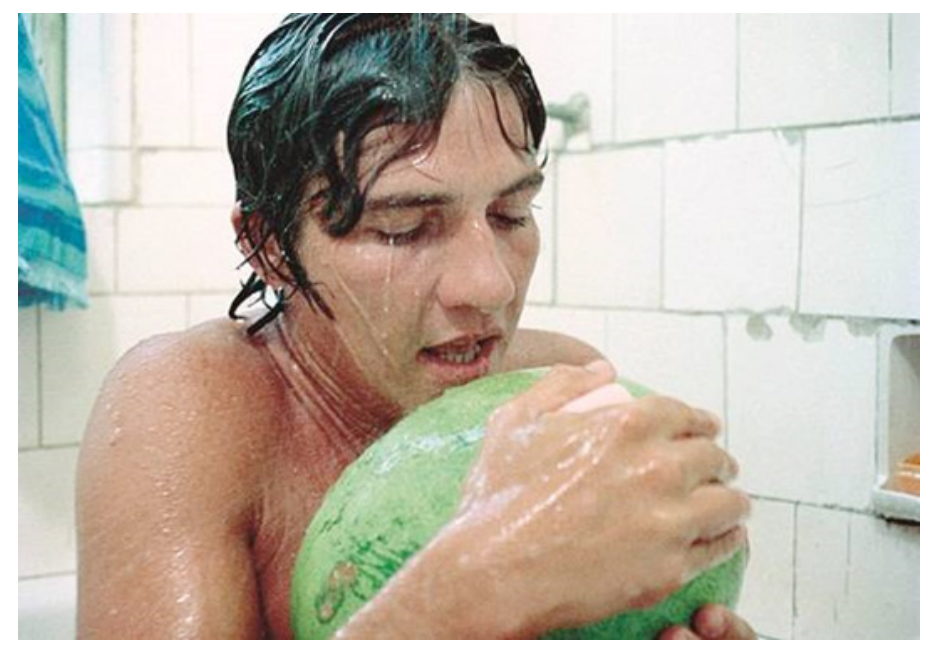

Figura 1: Cláudio Cavalcanti.

Fonte: Contos eróticos (1977)

As regras utilizadas pelo professor para dar vida à cena erótica começam a ficar mais nítidas. Ele passa a falar com a melancia e, pelo seu monólogo, podemos intuir o que ele ouve: "Fica quieta! Não foge de mim...". A essa altura, a melancia foge do professor para evitar o pretendido sexo oral que, então, à força, ele consegue fazer. Excitado, o professor penetra a melancia, mas logo para e se senta esgotado, lamentando-se: "Ejaculação prematura!". Ao enveredar pelo universo do grotescocarnavalizado, o filme logra

entrar em comunhão com a vida da parte inferior do corpo, a do ventre e dos órgãos genitais, e, portanto, com atos como o coito, a concepção, a gravidez, o parto, a absorção de alimentos e a satisfação das necessidades naturais. A degradação cava o túmulo corporal para dar lugar a um novo nascimento. (BAKHTIN, 1993, p. 19, grifo do autor)

Nessa primeira sequência, muito pode ser dito sobre o filme, inclusive inserindo o mesmo no universo contextual das pornochanchadas. O filme parece falar

${ }^{7}$ Canção de autoria de Gonzalo Curiel e interpretada por Carlos Galhardo. 
sobre os limites da perversão sexual. Mas nas sequências seguintes, as conversas entre o professor e sua confidente deixam claro o tema da liberdade, sexual ou política, o que se torna mais evidente se considerarmos que o filme foi feito durante a Ditadura Militar e dirigido por um cineasta como Joaquim Pedro de Andrade. Aliás, quando filmou "Vereda tropical", ele já tinha no currículo filmes relevantes para o período como Macunaíma (1969) e Os inconfidentes (1972).

O grotesco-carnavalizado se faz presente através das inversões e rebaixamentos que "Vereda tropical" promove, permitindo a confecção de uma obra tão irreverente quanto singular, falando e mostrando o que na época não poderia ser exibido de maneira concreta. O filme terminou por ser censurado, mas sem um motivo político aparente. Era apenas o tema da perversão que incomodava. A história do professor que transa com melancias parecia, para os censores, abaixo da crítica, da moral e dos bons costumes, o que não poderia ser diferente em se tratando de um filme que rompe totalmente com o estabelecido, o oficial, o que o senso comum considera ser apropriado e de bom-tom. Não é outro o movimento grotesco-carnavalizado que o filme promove, o da inversão carnavalesca e do rebaixamento grotesco.

Ao discorrer sobre a censura que "Vereda tropical" sofreu, Orlando Fassoni (1979) registra o depoimento de alguns profissionais envolvidos no filme ou nos demais episódios de Contos eróticos. Joaquim Pedro de Andrade, por exemplo, compara a carne da melancia a uma hóstia vegetal, mantendo presente em seu discurso sobre o filme o caráter grotesco-carnavalizado que vemos nas cenas. Já Eduardo Escorel, que além do episódio "O arremate", assina também a direção de fotografia de "Vereda tropical", ataca duramente os censores por terem como alvo a inteligência e a política, proibindo as possibilidades de reflexão e reforçando a passividade e a dominação das plateias.

Proibido no Brasil, o filme foi exibido na Quinzena dos Realizadores causando, segundo Leon Cakoff (1979), um verdadeiro furor no Festival de Cannes, tendo sido ainda convidado para participar de um festival nos Estados Unidos, a saber, o Festival New Directors/New Film, promovido pelo Museu de Arte Moderna de Nova Iorque. Aqui, onde se colocava em pauta a reabertura política, o filme permanecia proibido, já que os realizadores dos demais episódios foram solidários a Joaquim Pedro e decidiram não exibir o filme subtraindo o episódio da melancia. O filme só foi liberado em 1980, recebendo elogios da crítica:

Depois de muita proibição - e muita publicidade - as platéias verão finalmente Contos eróticos, e provavelmente acharão suas histórias meio tímidas diante do que tem sido apresentado no varejo cinematográfico. Em todo caso, trata-se de um filme bem-acabado, com boa produção em seus quatro episódios 
e um momento de altíssimo nível cinematográfico, "Vereda tropical", de Joaquim Pedro de Andrade, justamente a história que provocou todo o arrepio censório. (PEREIRA, 1980)

Chancelado pelo impacto e elogios que o filme recebeu nos festivais supracitados, "Vereda tropical" se afirmou como o grande interesse do longa, algo que permanece ainda hoje. A história do professor e sua aluna, seu contato livre e familiar, a excentricidade do protagonista e a ousadia da encenação continuam demonstrando vigor, sobretudo pelo trabalho de Joaquim Pedro na adaptação do conto. A personagem da amiga, por exemplo, foi criada para o filme. O conto é narrado em primeira pessoa e se limita à descrição da paixão de um homem por melancias. Já a profissão do protagonista, bem como sua relação com a amiga foram introduzidas por Joaquim Pedro de Andrade, o que proporciona algumas cenas nas quais as duas personagens interagem, em geral, tendo a ilha de Paquetá como pano de fundo.

Em seu passeio de barca com sua confidente, o professor explica o teor grotesco-carnavalizado, provocador do riso e irreverente de sua atitude. A inclinação cômica do filme vai além da excentricidade da situação e dá o tom dos diálogos escritos por Joaquim Pedro de Andrade.

Professor: Claro que tem um lado ridículo, até engraçado se você quiser. [...] Estou escrevendo minha tese, estou dando aula para quatro turmas. O dinheirinho que me resta é só para sobreviver mesmo, e para comprar uma melanciazinha de vez em quando. (CONTOS ERÓTICOS, 1977)

Vale ressaltar que o filme não mostra absolutamente nada. Não há mulheres nuas, tão frequentes nas pornochanchadas, que exploravam de forma intensa o corpo feminino. No entanto, o filme encena o sexo explícito como nenhum outro. Basta considerar o plano subjetivo através do qual vemos a penetração em si. Até então, nenhum filme de sexo explícito ou pornochanchada fora tão longe. A tela fica vermelha e vemos, rapidamente, a penetração se concretizando no interior da melancia, através de uma ousada estratégia de encenação.

A ligação do homem com a terra, princípio do material e corporal, encontra, aqui, uma representação radical. Ainda na barca, o professor assume as dificuldades que tem para encontrar melancias durante certo período do ano, conectando-se de vez à terra através de outras frutas e legumes.

Professor: Mas fruta tem problema de estação. No verão, tudo bem. Agora, já teve inverno de eu ter de apelar para berinjela, abacate, abóbora... Abóbora quase me mata. [...] É uma 
questão de relacionamento pessoal. Eu me dou bem mesmo é com melancia. Se pudesse fazer estoque na entressafra era uma boa, né? Também ia ter que comprar um frigorífico porque não tem geladeira que comporte aquele tamanho. (CONTOS ERÓTICOS,1977)

O encontro entre o professor e sua confidente não faz com que eles deixem de lado o caráter grotesco-carnavalizado de sua relação com as frutas e legumes. A cena da feira, no final, mostra o casal escolhendo os produtos que vão ser sexualmente consumidos depois, pelo que o filme sugere. Voltando para casa de bicicleta, uma melancia na garupa do professor e diversas frutas e legumes fálicos na cestinha da amiga, eles chegam a um denominador comum através da especulação de combinações sexuais possíveis, quando a amiga dá a solução final.

Amiga: Mas você acha que tem que ser solitário mesmo? [...] Professor: Não sei. Pode ser que misturando mais também dê certo. Por exemplo, pode ser um legume e uma fruta com uma pessoa $[\ldots]$.

Amiga: A mulher com dois legumes e o homem com uma fruta e com um legume. [...]

Professor: Não, nada disso! Acho que o negócio é eu, você e os hortifrutigranjeiros. (CONTOS ERÓTICOS, 1977)

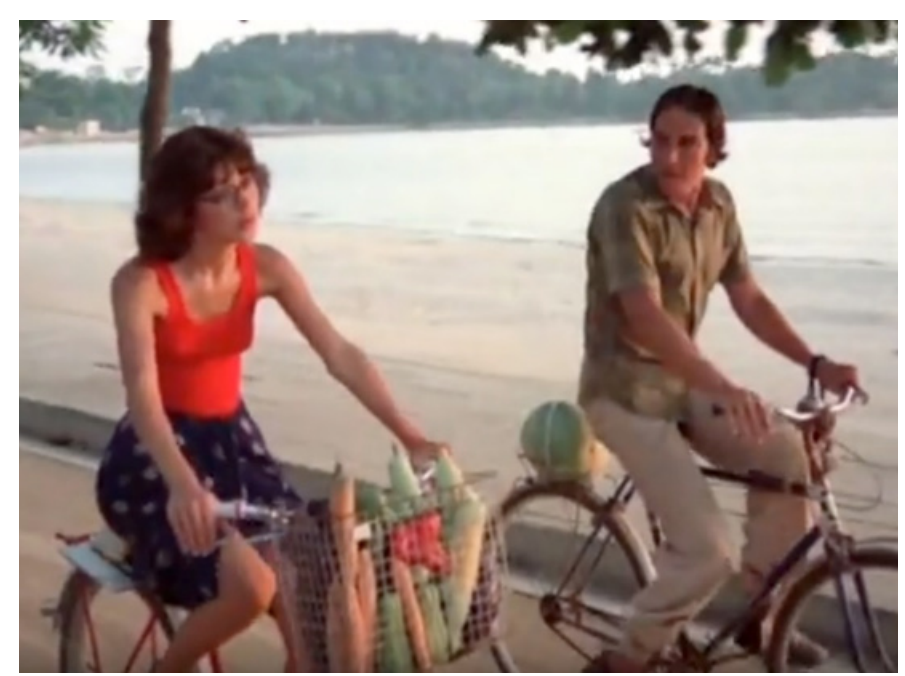

Figura 2: Cristina Aché e Cláudio Cavalcanti.

Fonte: Contos eróticos (1977) 
Com a ambiência grotesco-carnavalizada, contrasta a música interpretada por Carlos Galhardo, no insólito final que mostra uma representação teatral, o cantor e várias mulheres com um cenário romântico ao fundo. O filme coloca o apetite sexual e a satisfação das necessidades básicas no mesmo ponto. A melancia passa a ser digerida das duas formas possíveis, tomadas como um mesmo momento de prazer. Após transar com a melancia, o professor a esfaqueia e come misturada com seu sêmen. A fome sexual e a fome física são saciadas no mesmo instante. São os limites do rebaixamento e da inversão que "Vereda tropical" promove, elevando à máxima potência o referencial grotesco-carnavalizado do filme em falas como: "Eu bebo seu sangue. Como sua carne".

O encontro do homem com o mundo que se opera na grande boca aberta que mói, corta e mastiga é um dos assuntos mais antigos e mais marcantes do pensamento humano. O homem degusta o mundo, sente o gosto do mundo, o introduz no seu corpo, faz dele uma parte de si. (BAKHTIN, 1993, p.245)

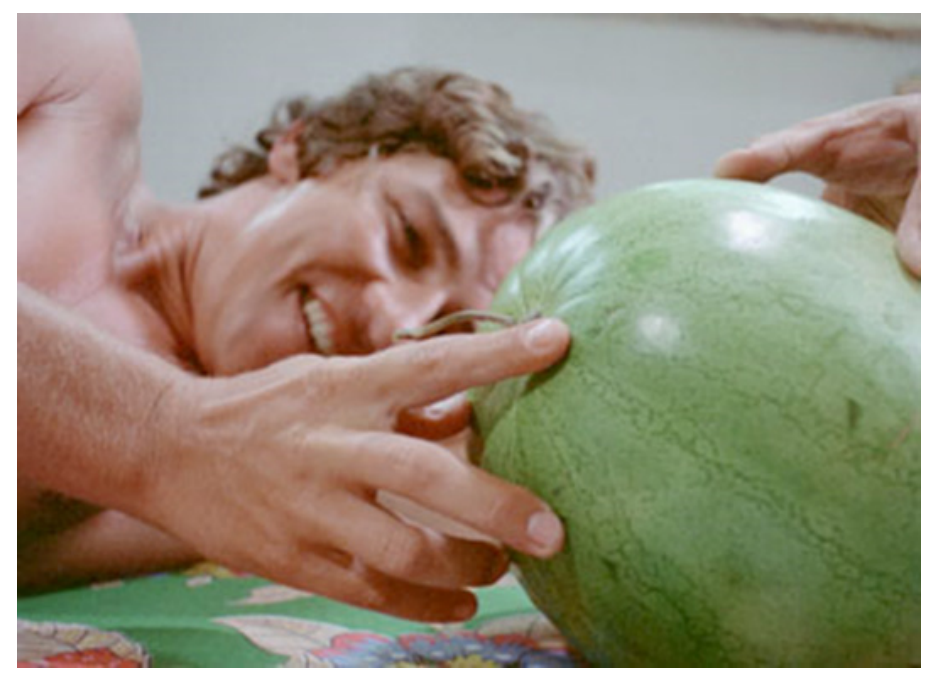

Figura 3: Cláudio Cavalcanti.

Fonte: Contos eróticos (1977)

O filme nos dá pistas concretas da dimensão de uma tradição do grotescocarnavalizado no cinema brasileiro. Aqui, o sexo é mostrado de forma lúdica, provocadora do riso, ao mesmo tempo em que fundamenta um universo sexual atípico, fora do comum, extraoficial. A inversão carnavalesca e o rebaixamento grotesco estão, assim, definitivamente atrelados. O grotesco-carnavalizado cinematográfico encontra 
na história do professor universitário que transa com melancias o seu mais irreverente representante no panorama do cinema brasileiro, ontem e hoje.

\section{Considerações finais}

Pouco mais de quarenta anos após a realização do filme, a cena contemporânea do cinema brasileiro não traz nenhum exemplar com o grau de ousadia de "Vereda tropical”. Apesar de alguns filmes já citados, como A marvada carne e Carlota Joaquina, a carnavalização e o grotesco ecoam em alguns de nossos filmes, mas nunca de maneira tão radical. Por um lado, o filme de Joaquim Pedro de Andrade pode ser considerado como fruto de um contexto repressivo dos anos da Ditadura Militar; por outro lado, talvez um certo conservadorismo estético tenha se tornado hegemônico no cinema brasileiro se considerarmos o gênero em que o filme se inscreve.

As comédias nacionais costumam atrair um público considerável às salas de cinema. Notadamente populares, esses filmes buscam dialogar com o grande público, mas é bastante nítido o grau de concessões e de falta de criatividade de boa parte dessa produção. A preocupação com a bilheteria pode reduzir o filme a um universo limitado de repetições e clichês, mesmo quando trata de um assunto tão presente em "Vereda tropical" como é o sexo. A relevância de resgatar um filme como este está na possibilidade de contribuir, através desse resgate, para uma reflexão sobre a potência do gênero, muitas vezes confinado ao vício das rentáveis franquias ou a estratégias de humor fácil. Analisar "Vereda tropical" pelo prisma da carnavalização e do grotesco se justifica, também, como uma estratégia de repensar um filme ímpar e mais ousado do que boa parte do cinema brasileiro contemporâneo.

A carnavalização e o grotesco nos ajudam a fazer uma nova leitura da obra de arte. A junção destes a partir da ideia de um filme grotesco-carnavalizado, como é o caso de "Vereda tropical", busca atrelar esses dois conceitos correlatos e inseparáveis. O filme é marcado pelo princípio do material e do corporal, pela excentricidade, pelo contato livre e familiar entre professor e aluna, pela comida e pelo sexo colocados no mesmo patamar. $\mathrm{O}$ enriquecimento que o grotesco-carnavalizado oferece à análise é diretamente proporcional à complexidade das camadas de leitura que se abrem, e é justamente nisso que reside a atualidade e força do universo conceitual bakhtiniano quando este se encontra com o cinema brasileiro.

A partir do uso do grotesco-carnavalizado, procuramos identificar passagens e situações que nos permitissem classificar "Vereda tropical" como um filme marcado por tais conceitos, dentro de uma tradição provocadora do riso através da inversão carnavalesca e do rebaixamento grotesco. Esse filme pode ser pensado a partir de 
uma filiação à tradição do grotesco-carnavalizado no Brasil, mas sua singularidade é evidente quando comparado ao cinema brasileiro contemporâneo.

Revisitar "Vereda tropical" sob um olhar bakhtiniano nos ajuda a escutar as diversas vozes no filme, no conto e no seu entorno. Como diria Bakhtin, tudo o que é expresso por um falante não pertence só a ele. Em todo discurso/texto/filme é possível ouvir vozes, quase inaudíveis, além da voz do autor, além das vozes dos personagens. Essas vozes, anônimas, impessoais, são vozes da nossa História e que nos transformam no que somos hoje; nossa arte, nossa vida, nossa cultura, nosso cinema.

\section{Referências}

BAKHTIN, M. A cultura popular na Idade Média e no Renascimento: o contexto de François Rabelais. São Paulo: Hucitec, 1993.

BAKHTIN, M. Problemas da poética de Dostoievski. Rio de Janeiro: Forense Universitária, 1982.

BARROS, D. "Dialogismo, polifonia e enunciação". In: BARROS, D.; FIORIN, J. (org.). Dialogismo, polifonia, intertextualidade: em torno de Bakhtin. São Paulo: Edusp, 2003. p. 1-8.

BERNARDET, J.-C. "O escândalo da melancia". In: MANTEGA, G. Sexo e poder. São Paulo: Brasiliense, 1979. p. 99-101.

BURKE, P. A cultura popular na Idade Moderna. São Paulo: Companhia das Letras, 1989.

CAKOFF, L. "Cannes - Joaquim causa furor com seu conto erótico". Correio Braziliense, Brasília, DF, 22 mai. 1979. Disponível em: http://bit.ly/2GYBcVS. Acesso em: 20 mai. 2018.

CAÑIZAL, E. P. "Breves anotações sobre a carnavalização e alguns de seus disfarces em dois filmes latino-americanos: Como água para chocolate e Carlota Joaquina". Significação, São Paulo, v. 32, n. 24, p. 23-42, 2005.

FASSONI, O. L. "A censura proíbe A Melancia”. Folha de São Paulo, São Paulo, 31 jan. 1979. Disponível em: http://www.filmesdoserro.com.br/mat_vt_01.asp. Acesso em: 22 mai. 2018.

HUGO, V. Do grotesco ao sublime: tradução do "Prefácio de Cromwell". São Paulo: Editora Perspectiva, 1988.

KAYSER, W. O grotesco. São Paulo: Editora Perspectiva, 1986. 
KOTHE, F. “Paródia e cia”. Tempo Brasileiro, Rio de Janeiro, n. 62, p. 97-111, 1980.

DAMATTA, R. Carnavais, malandros e heróis: para uma sociologia do dilema brasileiro. Rio de Janeiro: Rocco, 1997.

DAMATTA, R. Ensaios de antropologia estrutural. Petrópolis: Vozes, 1973.

PEREIRA, E. "Erotismo ao jeito brasileiro, agora sem censura". O Estado de São Paulo, São Paulo, 17 mar. 1980. Disponível em: http://bit.ly/2IUH0BR. Acesso em: 22 mai. 2018.

SANTANA, A. R. de. Paródia, paráfrase e cia. São Paulo: Ática, 2000.

SOARES, P.M. "Vereda tropical”. Revista Status, Rio de Janeiro, 1976. Disponível em: http://bit.ly/2LilfOk. Acesso em: 20 mai. 2018.

SODRÉ, M.; PAIVA, R. O império do grotesco. Rio de Janeiro: Mauad, 2002.

SODRÉ, M. Comunicação do grotesco. Rio de Janeiro: Vozes, 1972.

STAM, R. Bakhtin: da teoria literária à cultura de massa. São Paulo: Ática, 1992.

\section{Referências audiovisuais}

AMÉLIA. Ana Carolina, Brasil, Brasil, 2000.

A MARVADA carne. André Klotzel, Brasil, 1985.

CARLOTA Joaquina, princesa do Brasil. Carla Camurati, Brasil, 1995.

CONTOS eróticos. Roberto Santos, Roberto Palmari, Eduardo Escorel, Joaquim Pedro de Andrade, Brasil, 1977.

MACUNAÍMA. Joaquim Pedro de Andrade, Brasil, 1969.

OS INCONFIDENTES. Joaquim Pedro de Andrade, Brasil, 1972.

submetido em: 23 mai. 2018 | aprovado em: 20 mar. 2019 